\title{
HEEFT IN SURINAME EEN VRUCHTENBEDRIJF KANS VAN SLAGEN? \\ DOOR
}

W. R. MENKMAN

Toen omstreeks 18 jaar geleden de doodsklok luidde voor de Surinaamsche bacovencultuur, toen had het den schijn alsof aan alle verwachtingen welke ooit waren gekoesterd van Suriname als vruchtenexporteerend land voor goed de bodem was ingeslagen en het heeft lang geduurd voordat h. t. l. wederom noemenswaardige aandacht werd geschonken aan de vraag of er in onze twaalfde provincie toch misschien mogelijkheden aanwezig zijn, voor den opbouw eener voor uitvoer werkende cultuur van tropisch of sub-tropisch fruit. Dat er de allerlaatste jaren weder eenige belangstelling voor het onderwerp in kwestie valt op te merken, is vooral het gevolg van de pogingen welke de Heer C. L. Tomson heeft aangewend om aan te toonen dat de teelt speciaal van citrussoorten en ananas in Suriname succes zou kunnen hebben.

Op een bijeenkomst van 17 December j.l. der Westindische groep van het Indisch Genootschap, waarin dezeaangelegenheid uitvoerig werd besproken, zijn wel niet veel nieuwe gezichtspunten geopend kunnen worden, maar vooral de discussies welke gevolgd zijn op de voordrachten van den Heer Tomson en van den Heer J. A. Liems leveren een gereede aanleiding op om de kwestie waarom het hier gaat nog eens te belichten.

Men kan die kwestie als volgt zien. De reeds in Suriname bestaande en gemakkelijk uit te breiden aanplant van alom bekende vruchten zou - direct of binnen korten tijd - voldoende grondstof kunnen leveren om de oprichting te rechtvaardigen eener onderneming welke zich zou 
bezighouden met den opkoop van het fruit en met de fabriekmatige verwerking ervan tot algemeen gangbare vruchtenconserven en tot uit vruchten verkregen producten welke een rol spelen in verschillende industrieën; bijzonder daarvoor geschikte vruchten zouden in matige hoeveelheden en binnen een niet te groot rayon in verschen toestand kunnen worden uitgevoerd. Een zoodanige onderneming zou wel niet van stonde af aan in belangrijke mate kunnen bijdragen tot de opleving van den Surinaamschen landbouw en daardoor tot verhooging van de Surinaamsche welvaart, maar het streven om een dusdanig bedrijf tot stand te brengen verdient niettemin aandacht en belangstelling. Waar de economische toestand zóó slecht is als in Suriname, daar behoort iedere uiting van ondernemingsgeest en vertrouwen in de toekomst met vreugde te worden begroet.

De gelegenheid evenwel tot geregelden afzet, tegen desnoods lage, maar min of meer stabiele prijzen, welke een industrie als de bedoelde ter plaatse zou scheppen, zou prikkelen tot verdere uitbreiding der cultuur en betrekkelijk spoedig zou de toestand kunnen ontstaan dat men alleen door uitvoer in verschen staat op grootere schaal de vruchtenproductie meester zou kunnen blijven. Het bedrijf zou zich dan verder moeten kunnen ontwikkelen in een richting, juist tegengesteld aan die van den opzet, $d$. w. z. dat het fabriekmatige bijzaak zou moeten worden verwerking van het voor verzending minder geschikte fruit - en de uitvoer in verschen toestand hoofdzaak; een ommekeer welke zich in betrekkelijk korten tijd zou moeten kunnen voltrekken.

Stelt men zich een dusdanigen gang van zaken voor oogen, dan is er natuurlijk wel degelijk aanleiding om te spreken van een algemeen economisch belang, want uitvoer van versch fruit, uit den aard der zaak naar verafgelegen consumptiegebieden, laat zich anders dan op tamelijk groote schaal voor Suriname moeilijk denken. En zoodra wij er ons maar even in verdiepen welk complex van omstandigheden zal moeten samenwerken om van Suriname een belangrijk vruchtenland te maken, dan rijzen 
onmiddellijk allerlei moeilijke vraagstukken in onze gedachten op, vraagstukken welke door niemand, onverschillig over welke ervaringen hij moge beschikken, zoo maar kunnen worden opgelost.

Er bestaat in de Vereenigde Staten een particulier bureau voor statistiek en documentatie, dat door een reeks van pakkende advertenties voortdurend die talrijke gevallen onder de oogen van het publiek brengt waarin door „wrong guesses” groote kapitalen verloren zijn gegaan en slechts teleurstelling het deel is geworden van hen die gemeend hadden iets groots te kunnen tot stand brengen; natuurlijk moeten door die sprekende annonces belanghebbenden er toe gebracht worden om van de diensten van het bureau gebruik te maken. Wie niet verkeerd gegist hebben, dat zijn de twee mannen geweest - de eene een Duitscher, de andere een Amerikaan - die in de zestiger jaren der vorige eeuw - waarschijnlijk zonder de hulp van eenig voorlichtingsinstituut - den uitvoer van bananen hebben georganiseerd, van Centraal Amerika en van Jamaica, naar de Vereenigde Staten. Hun bescheiden opzet heeft den eersten stoot gegeven tot het ontstaan van de groote combinatie op het gebied van de cultuur, het vervoer en den verkoop van fruit, die thans een zoo groote plaats inneemt in de economische en commercieele betrekkingen der Amerikaansche landen onderling en ook op de Europeesche markten een rol is gaan spelen.

Evenwel, de positie van Suriname is een zóó bijzondere en de tijdsomstandigheden zijn zóó verschillend van die waaronder de hoogerbedoelde pioniers werkten, dat hun voorbeeld allerminst voldoende houvast zou opleveren met betrekking tot een Surinaamsche vruchtencultuur op groote schaal. Evenals zij er zich van bewust moeten zijn geweest dat een groot succes slechts mogelijk was wanneer hun kijk op de toekomst juist zou blijken, zoo zal ook een Surinaamsche vruchtencultuur en vruchtenexport slechts kunnen slagen wanneer zekere nog niet bestaande condities te voorschijn zullen kunnen worden geroepen, of conform de verwachtingen zullen optreden. En dat in een kort tijdsverloop, want een zeer langzame en geleide- 
lijke ontwikkeling is, in verband met de ligging van Suriname, minder goed denkbaar.

Zou dus de factor ,,guesswork" niet kunnen worden uitgeschakeld, daarmede is nog niet gezegd dat reeds in haar tegenwoordig stadium de zaak als te speculatief zou moeten worden beschouwd om ernstige overweging te rechtvaardigen. Daarvoor roept niet alleen de Surinaamsche toestand te hard om middelen ter verbetering, maar daarvoor is ook de suggestieve werking te groot welke uitgaat van de steeds toenemende aanvoeren van sub-tropisch en tropisch fruit in Noord-West Europa, uit Klein-Azië, Zuid- en West-Afrika, Centraal- en Zuid-Amerika, om niet te spreken van de Noordamerikaansche markten. De vraag welke beteekenis de vruchtencultuur zou kunnen hebben voor Suriname, met zijn tropisch klimaat, zijn productieven bodem, zijn landbouwende gekleurde bevolking en zijn uitgestrekt net van bruikbare waterwegen, laat hem die haar eenmaal aan zich zelf gesteld heeft niet licht meer los.

Heel weinig landen zijn zóó misdeeld dat zij niet in eenig opzicht op natuurlijke voordeelen kunnen bogen. In welke mate is Suriname bevoorrecht ten aanzien van de mogelijkheid eener vruchtencultuur in het groot; voor de teelt van welke vruchten leent zich het land meer in het bijzonder; moet de vruchtencultuur beschouwd worden als bij uitstek plantagecultuur, of biedt zij ook mogelijkheden als volkscultuur; kan zij gecombineerd worden met de teelt van andere gewassen, of eischt zij de aandacht van den planter voor zich alleen op?

Met betrekking tot het overzeetransport is de toestand van dien aard dat een zich aanpassen van de zijde der scheepvaart aan de eigenaardige behoeften van den fruitexport, zoodra Suriname aan speciale scheepsruimte voor den uitvoer van versche vruchten behoefte zou krijgen, allerminst van zelf sprekend is. Zeer waarschijnlijk zou omgekeerd de cultuur van stonde af aan rekening moeten houden met de voorwaarden waaraan voldaan moet worden om een geregelde verbinding met de afzetgebieden mogelijk te maken. Hoe zou de vruchtencultuur moeten wor- 
den ingericht om zooveel mogelijk gelijkmatige verschepingen te verkrijgen; over welken afstand kunnen bepaalde vruchten in verschen staat worden vervoerd, zonder dat speciale voorzieningen noodig zijn met betrekking tot temperatuur en ventileering; op welke vrachtprijzen zou - alle omstandigheden in aanmerking genomen gerekend moeten worden?

In de Vereenigde Staten heeft zich - hand aan hand met den economischen uitbouw na den burgeroorlog een aanzienlijke invoer ontwikkeld van uitheemsch fruit in verschen toestand; ook in Canada neemt het gebruik van niet in het land zelf geteeld fruit toe en in bepaalde Europeesche landen valt hetzelfde verschijnsel te constateeren. Daarnaast echter heeft in de beide Noordamerikaansche landen de eigen inheemsche vruchtenteelt een hooge vlucht genomen; tot de Unie behooren subtropische en dichtbij gelegen tropische gebieden; Canada maakt deel uit van het groote Britsche imperium, tezamen o.a. met één Zuid- en één Centraalamerikaansch land, alsmede een aantal Westindische eilanden; Europa heeft in de Middellandsche Zeelanden dichtbije subtropische productiegebieden. Dit alles is vooral van beteekenis in verband met het protectionistisch streven van onzen tijd - aan beide zijden van den oceaan - een streven in niet geringe mate ook gericht op bescherming van den eigen landbouw. Welke afzetmogelijkheden bestaan er onder deze omstandigheden voor Surinaamsch fruit in verschen toestand, als stapelproduct wel te verstaan, op de Amerikaansche en Europeesche markten?

Resumeerende moge er nog eens de aandacht op worden gevestigd dat het vraagstuk der Surinaamsche vruchtencultuur drieledig is; het gaat bij dit vraagstuk om cultuurmogelijkheden, om vervoermogelijkheden en om afzetmogelijkheden. Elk dezer drie factoren staat te zeer op zich zelf dan dat verwacht zou kunnen worden dat, wanneer slechts met betrekking tot één een bevredigende oplossing is gevonden, de beide andere ,will take care of themselves".

Bestond er een speciale economische voorlichtings- 
dienst ten behoeve van onze West, dan zou allicht het probleem der Surinaamsche vruchtenteelt reeds lang van alle kanten zijn bestudeerd; een dergelijke organisatie trouwens zou ook veel ander nuttig werk te doen vinden en niet alleen in het belang van Suriname; men denke maar eens aan onze verwaarloosde en vergeten Bovenwindsche eilandjes.

In de allereerste plaats echter is het de voor Suriname zoo noodige welvaartspolitiek welke gediend zou zijn door van onbevangen zijde verzamelde gegevens, vooral waar het vraagstukken geldt als het hier behandelde, dat zoo verschillende aspecten heeft en niet door éénzijdig-deskundigen in zijn geheel kan worden overzien.

De voor de Surinaamsche aangelegenheden verantwoordelijke leiding behoort in staat te zijn ten aanzien van dat vraagstuk haar houding te bepalen, omdat nu eenmaal zonder overheidsbemoeienis in Suriname niets tot stand kan komen, of op den duur die bemoeienis niet kan worden ontgaan. Alleen reeds ten gevolge van het feit dat het plantagebedrijf niet meer de aanvoerkosten betaalt der eigen arbeiders is de overheid van stonde afaan partij bij alles wat er op landbouwgebied wordt ondernomen; om niet te spreken van de gewezen plantage-arbeiders, die als kleine landbouwers voorloopig zorgekinderen van het bestuur blijven.

Wat beteekent tegenwoordig de Surinaamsche uitvoer? Ter zijde latende het mijnproduct bauxiet, blijft er aan voortbrengselen van landbouw en boschexploitatie een 20.000 ton per jaar over, wat zeker voor een landbouwgewest met 150.000 inwoners bedroefd weinig is; en dat het niet voldoende is om den noodzakelijken invoer te betalen blijkt uit de handelsbalans, ook al vertoont die af en toe schijnbaar een voordeelig saldo. Suriname leeft - en dat reeds lang - ten deele ten koste van het buitenland, d. w. z. van het moederland.

Vermeerdering van uitvoer is wel het allereerste waarnaar moet worden gestreefd, vooral naar vermeerdering van uitvoer zonder dat daarvoor een evenredige vermeerdering van het aantal producenten vereischt wordt; dat 
het Surinaamsche probleem teruggebracht zou moeten worden tot een te kort aan bevolking is maar zéér betrekkelijk waar. Alle producenten zijn tevens consumenten en consumenten die behalve allereerste levensbehoeften ook bestuurszorg van allerlei aard noodig hebben; dit mag zeker niet uit het oog worden verloren, maar gelukkig staat daartegenover dat althans voedingsmiddelen voor de massa der bevolking grootendeels van eigen bodem kunnen worden verkregen.

Middelen te willen aangeven waardoor Suriname er als bij tooverslag bovenop zou komen is even nutteloos als het zoeken naar den steen der wijzen, maar niettemin zou er een groote stap vooruit zijn gedaan wanneer het voor export beschikbare overschot der bovengrondsche voortbrengselen - thans één lading voor een matig groot Hollandsch binnenvaartuig per week - op gezonde wijze zou zijn toegenomen tot één lading voor een flink oceaanschip per week. 